\title{
The disabling role of fluctuations in physical activity in patients with chronic low back pain.
}

Citation for published version (APA):

Huijnen, I. P. J., Verbunt, A. M. C. F., Roelofs, J., Goossens, M. E. J. B., \& Peters, M. L. (2009). The disabling role of fluctuations in physical activity in patients with chronic low back pain. European Journal of Pain, 13(10), 1076-1079. https://doi.org/10.1016/j.ejpain.2008.12.008

Document status and date:

Published: 01/01/2009

DOI:

10.1016/j.ejpain.2008.12.008

Document Version:

Publisher's PDF, also known as Version of record

Document license:

Taverne

Please check the document version of this publication:

- A submitted manuscript is the version of the article upon submission and before peer-review. There can be important differences between the submitted version and the official published version of record.

People interested in the research are advised to contact the author for the final version of the publication, or visit the DOI to the publisher's website.

- The final author version and the galley proof are versions of the publication after peer review.

- The final published version features the final layout of the paper including the volume, issue and page numbers.

Link to publication

\footnotetext{
General rights rights.

- You may freely distribute the URL identifying the publication in the public portal. please follow below link for the End User Agreement:

www.umlib.nl/taverne-license

Take down policy

If you believe that this document breaches copyright please contact us at:

repository@maastrichtuniversity.nl

providing details and we will investigate your claim.
}

Copyright and moral rights for the publications made accessible in the public portal are retained by the authors and/or other copyright owners and it is a condition of accessing publications that users recognise and abide by the legal requirements associated with these

- Users may download and print one copy of any publication from the public portal for the purpose of private study or research.

- You may not further distribute the material or use it for any profit-making activity or commercial gain

If the publication is distributed under the terms of Article $25 \mathrm{fa}$ of the Dutch Copyright Act, indicated by the "Taverne" license above, 


\title{
The disabling role of fluctuations in physical activity in patients with chronic low back pain
}

\author{
Ivan P.J. Huijnen ${ }^{\mathrm{a}, *}$, Jeanine A. Verbunt ${ }^{\mathrm{b}, \mathrm{c}}$, Jeffrey Roelofs ${ }^{\mathrm{a}}$, Marielle Goossens ${ }^{\mathrm{a}}$, Madelon Peters ${ }^{\mathrm{a}}$ \\ ${ }^{a}$ Department of Clinical Psychological Science, Maastricht University, P.O. Box 616, 6200 MD Maastricht, The Netherlands \\ ${ }^{\mathrm{b}}$ Rehabilitation Foundation Limburg, P.O. Box 88, 6430 AB Hoensbroek, The Netherlands \\ ${ }^{\mathrm{c}}$ Department of General Practice, Maastricht University, P.O. Box 616, 6200 MD Maastricht, The Netherlands
}

\section{A R T I C L E I N F O}

\section{Article history:}

Received 6 May 2008

Received in revised form 10 December 2008

Accepted 22 December 2008

Available online 31 January 2009

\section{Keywords:}

Chronic low back pain

Activity level

Pain intensity

Electronic diary

\begin{abstract}
A B S T R A C T
Patients with chronic low back pain (CLBP) often report a disabling decrease in their activity level due to pain. The nature of the association between disability, activity, and pain over time is however, unclear. An intriguing issue here is whether a high level of pain-related disability is associated with a low activity level or are changes in the level of activity over time pain provoking and thus more disabling? The objectives of this study were to investigate associations between disability, pain intensity, pain-related fear, and characteristics of physical activity in patients with CLBP. A total of 42 patients with CLBP were recruited from the Pain Clinic of the Maastricht University Hospital. Each pain patient carried an electronic diary for one week, in which questions about current pain intensity, and the level of physical activity were completed at 8 moments a day. Disability was scored by the Quebec Back Pain Disability Scale (QBPDS), Fear of movement by the Tampa Scale for Kinesiophobia (TSK). To explain the level of disability regression analyses were performed with disability as dependent variable and pain intensity, painrelated fear, and consecutively the level of physical activity in daily life and fluctuations in physical activity as independent variables. Results, based on 34 patients, showed that activity fluctuations $(\beta=0.373$, $p<0.05)$ rather than the mean activity level over time $(\beta=-0.052$, ns) contributed significantly in explaining disability. The results are discussed in the light of current theories, previous research, and clinical implications.
\end{abstract}

(c) 2009 European Federation of International Association for the Study of Pain Chapters. Published by Elsevier Ltd. All rights reserved.

\section{Introduction}

Patients with chronic low back pain (CLBP) often feel disabled in performing daily activities. According to the fear-avoidance model of chronic pain, these patients may have catastrophic thoughts about their pain resulting in fear of pain, which is characterised by escape and avoidance behavior. Eventually, avoidance leads to disability, depression, and disuse, which fuel the pain experience resulting in a vicious cycle. Individuals who do not catastrophize about their pain will not become fearful and will expose themselves to daily activities leading to recovery (Vlaeyen and Linton, 2000; Leeuw et al., 2007). Although the role of fear avoidance in explaining disability has been confirmed in a wide range of patients with chronic pain, not all patients show a decreased activity level (Naliboff et al., 1985; Nielens and Plaghki, 2001; Verbunt et al., 2001; Liszka-Hackzell and Martin, 2004; van den Berg-Emons et al., 2006). In addition, several studies could not confirm the hypothesized association between physical activity and disability

\footnotetext{
* Corresponding author. Tel.: +31 433882487; fax: +31 433884155.

E-mail address: i.huijnen@dmkep.unimaas.nl (I.P.J. Huijnen).
}

(Vendrig and Lousberg, 1997; Verbunt et al., 2001; Liszka-Hackzell and Martin, 2004).

In order to unravel the complex associations between physical activity, pain and disability in chronic pain, Hasenbring proposed an alternative strategy. According to the avoidance endurance model, some patients apply endurance coping and tend to finish their activities despite pain (Hasenbring et al., 2001). Like avoiders, this subgroup of "persisters" will report an increased level of disability, but their activity level seems to be normal to even high as compared to healthy individuals (Hasenbring et al., 2001, 2006). Recently, McCracken and Samuel (McCracken and Samuel, 2007) have identified a group of "doers" which closely resemble the "persisters". "Persisters" are likely to continue with activities until pain prevents them from any further activity. This results in complete rest until pain subsides or frustration over inactivity stimulates them to start a new activity (Harding and Williams, 1998; Hasenbring et al., 2001). As a result of this, their level of activity seems to be characterised by a "sawtooth" pattern, indicating that it fluctuates highly over time. According to this theory, for a subgroup of patients, activity fluctuations could even be more disabling than the actual activity level. 
In order to study the disabling role of changes in activity, the level of activities has to be assessed in a certain timeframe. Most studies addressing the association between activity and disability relied on self-report measures that are prone to self-report bias. In the present study we used a momentary sampling strategy method, called experience-sampling method (ESM), to diminish the chance of bias (Csikszentmihalyi and Larson, 1987). ESM uses randomly sampled self-reported measures to gain more insight in relationships of variables assessed over time and to avoid retrospective recall (deVries, 1987).

In the current study, the influence of pain intensity, pain-related fear, level of physical activity and fluctuations in the activity level in explaining disability in patients with CLBP was studied.

\section{Methods}

\subsection{Participants and procedure}

Patients with chronic low back pain, who were referred to the Pain Clinic of Maastricht University Hospital, were recruited for participation in this study (Roelofs et al., 2004b). Inclusion criteria were (a) experiencing low back pain for at least 6 months and (b) age between 18 and 65. Exclusion criteria were (a) serious visual deficit and deafness; (b) being non-fluent in Dutch; (c) having difficulty holding a pen or writing; (d) serious psychiatric diseases; (e) alcohol and/or drug problems; and (f) having participated in a previous ESM study. After signing the informed consent, all participants were informed that the main aim of this study was to investigate how pain was experienced during the day and what factors influence pain. Participants completed a battery of self-report measures and carried a palm-top computer (type palm m100) with a dairy function in a protective case during 7 days. Participants were instructed that an alarm would randomly go off eight times a day and that at that moment patients had to fill in questions. Diary questions were presented on-screen for completion via a touch screen $(50 \times 50 \mathrm{~mm})$ and entries were time- and date-stamped. Participants could delay answering for $20 \mathrm{~min}$ when engaged in an activity that could not be interrupted. The maximum number of beeps per week was 56 . In case less than $50 \%$ of all registration moments were entered in the palmtop by the patient, data were excluded from further analyses. Participants were paid 25 Euro in return for participation in the study. The study protocol was approved by the Ethics Committee of the Maastricht University Hospital and Maastricht University.

\subsection{Measurement}

All participants completed the Tampa Scale for Kinesiophobia (TSK; (Miller et al., 1991) and the Quebec Back Pain Disability Scale (Kopec et al., 1995). The TSK contains 17 items aimed at assessing fear of (re)injury due to movement. The Dutch version has been reported to be reliable and valid (Vlaeyen et al., 1995; Goubert et al., 2000; Roelofs et al., 2004a). Low back disability was assessed using the Quebec Back Pain Disability Scale (QBPDS). This scale contains 20 items of which each item is rated from 0 (No difficulty performing this activity) to 5 (Impossible to perform this activity). The original as well as the Dutch version of the QBPDS are valid and reliable (Kopec et al., 1995; Schoppink et al., 1996).

With respect to the diary assessment, current pain intensity was assessed with the item "Right now, I am in pain". Answer categories were presented in seven point Likert scales ranging from 1 to 7 , with 1 indicating the lowest possible score and 7 indicating the highest possible score. Furthermore, the level of subjectively reported physical activity level was assessed based on a self constructed item: "What was your effort between this and the previ- ous beep?" Answer categories were: 7 =exercise vigorously; 6 = exercise; 5 = cycling; 4 = climbing stairs; 3 = walking; $2=$ sitting; 1 = lying down.

\subsection{Data analysis}

For every participant, mean values are calculated for pain intensity, and the activity level assessed in the diary. These values (Pain ESM $_{\text {, and Activity }}$ ESM) were used in the analyses. In addition, in order to study activity fluctuations in daily life over time a Root Mean Square score for activities (Activity ${ }_{\text {RMS }}$ ) was calculated. The difference scores of all activity values as related to one score earlier were calculated. These difference scores can be positive or negative values and were squared. Thereafter, a mean value was calculated and finally, the root from this mean value was taken. The final score Activity RMS $_{\text {represents the intensity of activity fluctuations }}$ in daily life over time.

To provide a description of the study group, mean scores or percentages for demographic and pain-related variables were calculated. Furthermore, in order to study the interrelation between a patient's level of pain intensity, level of physical activity and fluctuations in the level of physical activity, associations between these variables were calculated based on Pearson correlations coefficients.

In order to study the relation between a patient's level of disability, pain intensity, pain-related fear, level of physical activity, and fluctuations in the level of physical activity the interrelation between variables was studied in a hierarchical multiple regression analysis. A blockwise entry of variables with disability as dependent variable was used. In the first step fear of movement, Pain $_{\text {ESM, }}$ Activity ${ }_{E S M}$ were entered. In the second step, Activity ${ }_{\text {RMS }}$ was added to the equation, in order to study its unique contribution.

For all regression analyses, a colinearity check was performed. Colinearity was considered a problem when the variance inflation factor (VIF) was above 3. All statistical analyses were performed using SPSS software (SPSS Inc. Chicago, Ill).

\section{Results}

Forty-two participants (17 males, 25 females) with non-specific CLBP participated in the study. Five patients answered questions for less then $50 \%$ of the beeps of the palmtop, and their data were excluded for further analyses. None of the patients reported that he/she could not fill in the electronic diary due to their back pain. For three patients no Quebec Back Pain Disability Score was available. The final analyses were performed on 34 patients.

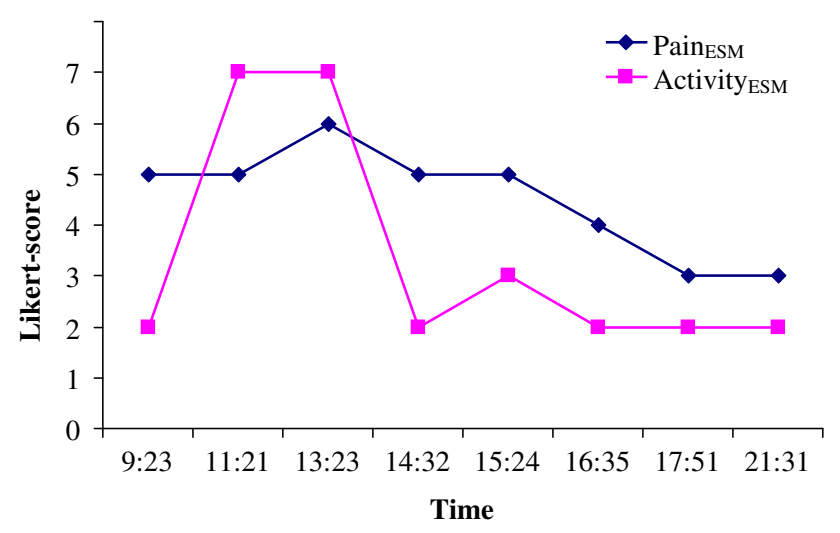

Fig. 1. An example of a day registration based on the ESM-method based on 8 at random samples. 
Table 1

Regression analyses with disability as dependent variable.

\begin{tabular}{llr}
\hline Step 1: & $R^{2}=0.309^{*}$, adjusted $R^{2}=0.240^{*}$ & \\
\hline Disability & Fear of movement & $\beta=0.236$ \\
& Pain $_{\mathrm{ESM}}$ & $\beta=0.525$ \\
& Activity $_{\mathrm{EMS}}$ & $\beta=0.158$ \\
Step 2: & $R^{2}=0.401^{* *}$, adjusted $R^{2}=0.318^{* *}$ & \\
\hline Disability & Fear of movement & $\beta=0.295$ \\
& Pain $_{\mathrm{ESM}}$ & $\beta=0.502^{*}$ \\
& Activity $_{\mathrm{EMS}}$ & $\beta=-0.052$ \\
& Activity & $\beta=0.373^{*}$ \\
\hline
\end{tabular}

$p<0.05$.

$p<0.01$.

The mean age of all participating patients was 45.4 years $(\mathrm{SD}=9.9)$. Mean pain duration was 156.5 months ( $\mathrm{SD}=116.9$ range 18-444). Mean disability level (QBPDS) for all patients was 55.97 (15.3) and their mean level for fear of injury 41.18 (8.7). The level of activity as scored by Activity $\mathrm{ESM}_{\mathrm{EM}}$ appeared to be significantly associated with the intensity of activity fluctuations over time (Activity RMS $)(0.57, p<0.01)$. Both Activity ity $_{\text {RMS }}$ were not associated with Pain ESM $_{\text {. }}$

In Fig. 1 an example of the result of a one-day ESM-registration of one patient is given. The diary recordings of all participants showed a mean Pain ${ }_{\mathrm{ESM}}$ score of 4.47 (1.04), a mean Activity

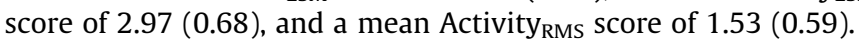

3.1. Associations between disability, pain intensity, fear of movement fluctuations in the activity level and the activity level for patients with CLBP

Table 1 presents the regression model explaining disability in patients with CLBP. In the first step Pain ESM $_{(}(p<0.01)$ explains disability. Fear of movement and Activity ${ }_{\mathrm{ESM}}$ had no significant contribution. In the second step Activity RMS $_{\text {was }}$ added in the regression model. In this step, Pain $_{\mathrm{ESM}}(p<0.01)$ and Activity ${ }_{\mathrm{RMS}}(p<0.05)$ both explained disability. In the second step, the contribution of fear of movement was nearly significant $(\beta=0.295, p=0.056)$. Activityesm did not have a significant contribution. In the final step, $32 \%$ of the variance in the level of disability could be explained $(p<0.01)$. All VIF factors were below 1.53 which indicated that there was no co linearity between Activityesm and Activity Rms. No outliers were present.

\section{Discussion}

The main aim of the present study was to study the role of physical activity and fluctuations in the activity level over time in explaining disability in patients with CLBP. Results indicated that fluctuations in the activity level seemed more associated with the level of disability as compared to the mean activity level over time in patients with CLBP.

The intensity of activity fluctuations over time was positively associated with a patient's perceived level of disability, whereas his/her mean activity level did not have any significant disabling influence. Although a high level of activity fluctuations seems natural in healthy individuals, for patients with chronic pain this could represent an activity pattern characterised by interfering involuntary rest stops due to pain. The high level of fluctuations could be a representation of the sawtooth pattern in their activities. Patients go on with their activities till the activity is finished and afterwards they have to take rest to recover. It could even be that, a lack of control regarding the performance of activities at any time is the underlying disabling factor. It might be possible that patients with more fluctuations in activity represent a pattern as described for the group of "doers" in the study of McCracken (McCracken and Samuel, 2007) or the "persisters" with endurance coping in the avoidance endurance model of Hasenbring (Hasenbring et al., 2001). However, this hypothesis cannot be confirmed based on the current results. More research is needed.

No association could be determined between pain intensity and the mean activity level or the fluctuations in activity. Earlier studies addressed the association between pain intensity and activity over time in patients with low back pain (Vendrig and Lousberg, 1997; Liszka-Hackzell and Martin, 2004). Pain intensity was associated with activity in the first 7 days of acute low back pain (LiszkaHackzell). However, in patients with chronic pain, in both studies, no association between pain and activity was found which is in accordance with our findings. In addition, we checked whether pain intensity was associated with the level of fluctuations in activity but could not confirm the presence of any relationship.

The current study contributes to the explanation of disability within the population of patients with CLBP and may have clinical implications. Till now, most research has been focused on explaining disability in "avoiders" based on the fact that a low activity level would be disabling. As a result, exposure in vivo and graded activities are evidence based interventions that now are regularly applied in clinical practice to reduce the disability level in "avoiders". However, it could be that patients who have a disabling fluctuating pattern in their activities, benefit more from learning strategies to fine tune their activities during the day instead of increasing their activity level. However, currently, no scientific basis is yet available to prove this statement.

The current study has some limitations that need to be addressed. The activity level and fluctuations in activity were derived from subjectively reported diary measures. It is known that for patients with chronic pain it is difficult to estimate their own physical activity level. However, it is important to note that thus far only self-report measures have been used and this diary study gives more insight in daily life functioning. Interestingly, a recent study by Bousema et al. (2007) and van der Werf et al. (2000) made an activity-related classification based on activity assessment by accelerometry (van der Werf et al., 2000; Bousema et al., 2007), which is also a promising direction for future research. More research is needed to further elucidate the characteristics of patients with chronic low back pain and to incorporate the various findings into a theoretical framework that can be used to apply treatment for activity-related subgroups in chronic pain. A second limitation of this study might be that using an electronic diary at several time points during a day could influence a patients' natural behavior. However, this assumed reactivity effect based on electronic dairy assessment in pain patients could not be confirmed in earlier studies on this topic (Cruise et al., 1996; Stone et al., 2003; Aaron et al., 2005).

In summary, in the current study it appeared that fluctuations in the activity level instead of the mean activity level over time could explain the level of disability.

\section{Acknowledgements}

This study was supported by the Council for Medical and Health Research of the Netherlands (ZON-MW), Grant No. 14350042. Participation of Dr. J. Roelofs was supported by the EFIC Grünenthal Grant.

\section{References}

Aaron LA, Turner JA, Mancl L, Brister H, Sawchuk CN. Electronic diary assessment of pain-related variables: is reactivity a problem? J Pain 2005;6(2):107-15.

Bousema EJ, Verbunt JA, Seelen HA, Vlaeyen JW, Knottnerus JA. Disuse and physical deconditioning in the first year after the onset of back pain. Pain 2007;130(3): 279-86. 
Cruise CE, Broderick J, Porter L, Kaell A, Stone AA. Reactive effects of diary selfassessment in chronic pain patients. Pain 1996;67(2-3):253-8.

Csikszentmihalyi M, Larson R. Validity and reliability of the experience-sampling method. J Nerv Ment Dis 1987;175(9):526-36.

deVries MW. Investigating mental disorders in their natural settings. J Nerv Ment Dis 1987;175(9):509-13.

Goubert L, Crombez G, Vlaeyen J, Van Damme S, Van Den Broeck A, Van Houdenhove B. De Tampa Schaal voor Kinesiofobie: Psychometrische karakteristieken en normering (The Tampa scale Kinesiophobia: psychometric properties and norms). Gedrag en Gezondheid 2000;28:54-62.

Harding V, Williams A. Activities training: intergrating behavioral and cognitive methods with physiotherapy in pain management. J Occup Rehabil 1998;8(1):47-60.

Hasenbring M, Hallner D, Klasen B. Psychological mechanisms in the transition from acute to chronic pain: over- or underrated? Schmerz 2001;15(6):442-7.

Hasenbring MI, Plaas H, Fischbein B, Willburger R. The relationship between activity and pain in patients 6 months after lumbar disc surgery: do pain-related coping modes act as moderator variables? Eur J Pain 2006;10(8):701-9.

Kopec JA, Esdaile JM, Abrahamowicz M, Abenhaim L, Wood-Dauphinee S, Lamping DL, et al. The Quebec Back Pain Disability Scale, measurement properties. Spine 1995;20(3):341-52.

Leeuw M, Goossens ME, Linton SJ, Crombez G, Boersma K, Vlaeyen JW. The fearavoidance model of musculoskeletal pain: current state of scientific evidence. J Behav Med 2007;30(1):77-94.

Liszka-Hackzell JJ, Martin DP. An analysis of the relationship between activity and pain in chronic and acute low back pain. Anesth Analg 2004;99(2):477-81 [table of contents].

McCracken LM, Samuel VM. The role of avoidance, pacing, and other activity patterns in chronic pain. Pain 2007;130(1-2):119-25.

Miller R, Kori S, Todd D. The Tampa scale. Unpublished report; 1991

Naliboff BD, Cohen MJ, Swanson GA, Bonebakker AD, McArthur DL. Comprehensive assessment of chronic low back pain patients and controls: physical abilities, level of activity, psychological adjustment and pain perception. Pain 1985;23(2):121-34.

Nielens H, Plaghki L. Cardiorespiratory fitness, physical activity level, and chronic pain: are men more affected than women? Clin J Pain 2001;17(2):129-37.

Roelofs J, Goubert L, Peters ML, Vlaeyen JW, Crombez G. The Tampa Scale for Kinesiophobia: further examination of psychometric properties in patients with chronic low back pain and fibromyalgia. Eur J Pain 2004a;8(5):495-502.

Roelofs J, Peters ML, Patijn J, Schouten EG, Vlaeyen JW. Electronic diary assessment of pain-related fear, attention to pain, and pain intensity in chronic low back pain patients. Pain 2004b;112(3):335-42.

Schoppink LE, van Tulder MW, Koes BW, Beurskens SA, de Bie RA. Reliability and validity of the Dutch adaptation of the Quebec Back Pain Disability Scale. Phys Ther 1996;76(3):268-75.

Stone AA, Broderick JE, Schwartz JE, Shiffman S, Litcher-Kelly L, Calvanese P. Intensive momentary reporting of pain with an electronic diary: reactivity, compliance, and patient satisfaction. Pain 2003;104(1-2):343-51.

van den Berg-Emons RJ, Schasfoort FC, de Vos LA, Bussmann JB, Stam HJ. Impact of chronic pain on everyday physical activity. Eur J Pain 2006.

van der Werf SP, Prins JB, Vercoulen JH, van der Meer JW, Bleijenberg G. Identifying physical activity patterns in chronic fatigue syndrome using actigraphic assessment. J Psychosom Res 2000;49(5):373-9.

Vendrig AA, Lousberg R. Within-person relationships among pain intensity, mood and physical activity in chronic pain: a naturalistic approach. Pain 1997;73(1):71-6.

Verbunt JA, Westerterp KR, van der Heijden GJ, Seelen HA, Vlaeyen JW, Knottnerus JA. Physical activity in daily life in patients with chronic low back pain. Arch Phys Med Rehabil 2001;82(6):726-30.

Vlaeyen JW, Kole-Snijders AM, Boeren RG, van Eek H. Fear of movement/(re)injury in chronic low back pain and its relation to behavioral performance. Pain 1995;62(3):363-72.

Vlaeyen JW, Linton SJ. Fear-avoidance and its consequences in chronic musculoskeletal pain: a state of the art. Pain 2000;85(3):317-32 